\title{
Race and Virulence Dynamics of Puccinia triticina in China During 2000-2006
}

\author{
T. G. Liu and W. Q. Chen, State Key Laboratory for Biology of Plant Diseases and Insect Pests, Institute of Plant Protection, Chinese \\ Academy of Agricultural Sciences, Beijing 100193
}

\begin{abstract}
Liu, T. G., and Chen, W. Q. 2012. Race and virulence dynamics of Puccinia triticina in China during 2000-2006. Plant Dis. 96:1601-1607.

Wheat leaf rust, caused by Puccinia triticina, is an important foliar disease of wheat in China. The dynamics of races and virulence in $P$. triticina populations in China during 2000 to 2006 were studied. Leaf rust samples were collected during surveys of wheat fields and trap nurseries in 16 provinces, and provided by coworkers throughout China. The virulence of single-pustule isolates was determined on near-isogenic Thatcher lines for leaf rust resistance genes $L r 1, L r 2 a, L r 2 c, L r 3, L r 9$, Lr16, Lr24, Lr26, Lr3ka, Lr11, Lr17, and Lr30, and races were denominated using the Prt code system. During 2000 to 2006, 79 races

were identified from a total of 613 isolates. Races PHT (23.7\%), THT (14.7\%), PHJ (11.4\%), and THJ (4.2\%) were the four common races, all avirulent to $\operatorname{Lr} 9$ and $L r 24$. The frequency of isolates with virulence to $L r 1, L r 2 c, L r 3, L r 11, L r 16, L r 17$, and $L r 26$ was over $80 \%$, and these isolates were widely distributed in China, whereas the frequencies of virulence to $\operatorname{Lr} 9, \operatorname{Lr} 19, \operatorname{Lr} 24, \operatorname{Lr} 25, \operatorname{Lr} 28$, and $\operatorname{Lr} 29$ were 0.2 to $2.5 \%$. The diversity of virulence phenotypes of Chinese $P$. triticina populations appeared to increase from 2000 to 2006. P. triticina races and virulences in China appear to be isolated from those in other countries.
\end{abstract}

Wheat leaf rust, caused by Puccinia triticina Erikss. (31), is the most common of the three rust diseases of wheat (Triticum aestivum L.) throughout the world. In China, it occurs annually on about 15 million ha of wheat, and the disease is especially common in the southwest and northwest areas, middle and lower Yangtze River Valley, and the southern Huang-Huai-Hai region (Huang [Yellow] River, Huai River, and Hai River regions). Severe leaf rust epidemics in 1969, 1973, and 1975 resulted in significant yield losses in north China (13). Monitoring the dynamics and variation of virulence to leaf rust resistance genes in the rust population provides the basis for anticipatory breeding of cultivars with optimum rust resistance, prediction of disease epidemics, and integrated disease control $(7,22,25)$.

Surveys of $P$. triticina races in China were first carried out in the 1940s (35), and three races (race 1, 63, and 123) were identified from samples from Yunnan Province based on infection type (IT) to the eight international differentials used by Johnston and Mains (17). However, the differential set of eight cultivars was not adequate for fully differentiating Chinese races of $P$. triticina. In the early $1970 \mathrm{~s}$, race surveys of $P$. triticina were conducted by several institutions, such as the Institute of Plant Protection, Chinese Academy of Agricultural Sciences; Henan, Shandong, and Helongjiang Academies of Agricultural Sciences; and Hebei Agricultural University. In 1977, eight wheat genotypes (Lovrin 10, 6068, IRN66-331, Redman, Dongfanghong 3, Fengchan 3, Baiyoubao, and Taishan 4) were chosen as Chinese unified $P$. triticina differentials based on their abilities to differentiate $P$. triticina isolates under varying temperatures and light regimes. Three races that were found at high frequency were designated as Chinese leaf rust (CLR)1 to CLR3 (37). Annual surveys of race and virulence of $P$. triticina using this differential set with some complementary wheat genotypes have been conducted throughout the major wheat-growing areas by the Chinese National Wheat Rust Collaborative Group

Corresponding author: W. Q. Chen, E-mail: wqchen@ippcaas.cn

Accepted for publication 22 May 2012.

http://dx.doi.org/10.1094/PDIS-06-10-0460-RE

(C) 2012 The American Phytopathological Society since $1977(6,14,23,36,40)$. The major virulence patterns were designated as CLR races with sequential numbers based on their chronological detection. By 1996, there were a total of 48 CLR races of $P$. triticina described in China.

Starting in 1989, a set of near-isogenic Thatcher lines developed by Dyck and Samborski (9) was introduced in China and has been used for surveying virulence of $P$. triticina from different wheatgrowing areas of China $(3,4,14,39,41)$. The races of $P$. triticina were designated using the North American Prt code system (23).

Over 60 officially designated genes for resistance to leaf rust $(\mathrm{Lr}$ genes), and many other temporarily designated $L r$ genes, have been described in wheat (27). Most of the genes condition race-specific resistance in a gene-for-gene relationship with $P$. triticina, and some have been used widely $(26,27)$. However, when resistance to an obligate pathogen such as rust is determined by a single gene, it is common to observe within a few years the evolution of a new pathogenic race capable of overcoming the resistance. Annual surveys of $P$. triticina virulence frequencies have provided valuable data for wheat-breeding programs and also helped to track virulence evolution over time. In general, changes in races and their virulences have corresponded to changes in wheat cultivars deployed in commercial wheat production. Similar surveys have been conducted in Canada since 1931 (15), the United States since 1926 (16,19,20), Australia since 1920 (38), and Mexico since 1988 (32). The objectives of this study were to determine the races and virulence dynamics of the P. triticina population in China during 2000 to 2006, and to compare the data with those of previous surveys.

\section{Materials and Methods}

Collection of leaf rust isolates. Leaf rust samples were usually collected in the spring and summer months when the fungus was most common. Each year, samples were taken from widely grown cultivars along a field survey route by researchers from the Institute of Plant Protection, Chinese Academy of Agricultural Sciences, and cooperators from regional Plant Protection Stations located in different epidemic zones throughout China (Fig. 1). Some samples were collected from trap nurseries established at 29 locations in 16 provinces for monitoring effectiveness of resistance to stripe rust, leaf rust, stem rust, and powdery mildew (5). Samples with visible $P$. triticina uredinia were temporarily stored at $4^{\circ} \mathrm{C}$ in a refrigerator until multiplication. All samples were sourced 
from field collections under natural infection. A collection consisted of one to several leaves with uredinia from a single plant or cultivar. The leaves were air dried and stored at $4^{\circ} \mathrm{C}$ until spores were collected for inoculation and increase. Collections from inoculated nurseries were not included in the study.

Multiplication of single-pustule isolates and harvest. The dried leaves were put on wet filter paper in covered petri dishes at room temperature overnight. Uredinia were collected with a scalpel and inoculated onto 7- to 8-day-old seedling leaves of susceptible 'Zhengzhou 5389' planted in pots with low-nutrient soils. After inoculation, wheat plants were then put in a dew chamber at 18 to $24^{\circ} \mathrm{C}$ in darkness for 18 to $24 \mathrm{~h}$. The inoculated wheat seedlings were then moved into a greenhouse with supplemental fluorescent light at 20 to $28^{\circ} \mathrm{C}$ in the daytime and 15 to $18^{\circ} \mathrm{C}$ at night. Each inoculated plant was placed in a glass cylinder with four layers of gauze on top to reduce cross-contamination. Using the same procedure, single-pustule isolates were increased on susceptible seedling plants. Isolates were collected by tapping or shaking the glass cylinder with an iron rod, and the urediniospores were put into tubes in desiccators.

Race and virulence identification. To determine races and virulences of $P$. triticina, the following set of near-isogenic Thatcher lines, each bearing a single resistance gene, was employed: Lr1, Lr2a, Lr2b, Lr2c, Lr3, Lr3bg, Lr3ka, Lr9, Lr10, Lr14a, Lr14b, Lr15, Lr16, Lr17, Lr18, Lr19, Lr23, Lr24, Lr26, $L r 29, L r 30, L r 32$, and Lr33. Also used were the lines Hussar, Thew, Transec(Awned), Gatcher, and CM2D-2M, which carried $L r 11, L r 20, L r 25, L r 27+31$, and $L r 28$, respectively. 'Thatcher' was used as a susceptible check. All of the tested wheat lines were grown together in 60-by-40-by-20-cm plastic trays. Each line was represented by 5 to 10 seedlings. Urediniospores of each isolate were inoculated onto 7-day-old seedlings of the 28 wheat lines in an automatic inoculation tower using urediniospores at 5 to 10 $\mathrm{mg} / \mathrm{ml}$ and $0.25 \mathrm{ml}$ of Soltrol 170 (Phillips 66 Company). After drying for $1 \mathrm{~h}$, the seedlings were put into a metal cylinder with a plastic cover for incubation at 18 to $24^{\circ} \mathrm{C}$ for $24 \mathrm{~h}$ at $100 \%$ relative humidity, and then placed on a bench in a greenhouse at 15 to $28^{\circ} \mathrm{C}$ with $8 \mathrm{~h}$ of supplemental fluorescent lighting.

IT scoring. The ITs on the first leaves were scored at 12 to 16 days post inoculation, when uredinia on Thatcher were fully developed. A 0 -to-4 scale $(24,31)$ was used for ITs: $0=$ no visible sign of infection; semicolon $(;)=$ no uredinia but small hypersensitive necrotic or chlorotic flecks of varying size; $1=$ small uredinia surrounded by necrosis; 2 = small to medium uredinia surrounded by chlorosis, a green island that may be surrounded by chlorotic border; $\mathrm{X}=$ random distribution of variable-sized uredinia and flecks on single leaf with a pure culture; $3=$ medium-sized uredinia that may be associated with chlorosis; $4=$ large uredinia without chlorosis; a plus symbol $(+)=$ slightly larger uredinia than expected for the IT; minus symbol $(-)=$ slightly smaller uredinia than expected for the IT; and $\mathrm{c}=$ more chlorosis than expected for the IT. Where different ITs were produced on the same line, the most common IT was listed first. A three-letter code based on the low or high ITs of each isolate to the 12 differential Thatcher lines was employed to describe races of $P$. triticina $(18,24)$.

Race or virulence diversity measurement. Diversity of race or virulence of $P$. triticina within areas and between years was determined with the Chao-1 estimator $\left(S^{*} 1\right)(2,8)$ and the calculator is provided courtesy of Niklaus J. Grünwald: $S^{*} 1=S_{o b s}+\left(a^{2} / 2 b\right)$, where $S_{o b s}$ is the number of races observed, $a$ is the number of races observed just once, and $b$ is the number of races observed just twice. Chao-1 is a nonparametric estimator which is not affected by sample size. In addition, a standard deviation $(\mathrm{Sd})$ is computed using $\mathrm{Sd}=b\left[(a /[4 b])^{4}+(a / b)^{3}+(a /[2 b])^{2}\right]$. The program prints " -1 " to indicate that $b=0$ and the Chao estimator cannot be computed.

The rarefaction method allows comparison of the number of species or, in this case, races found in two regions when the sampling effort differed. One would expect that greater sampling effort would yield a larger sample and more races. Rarefaction uses the
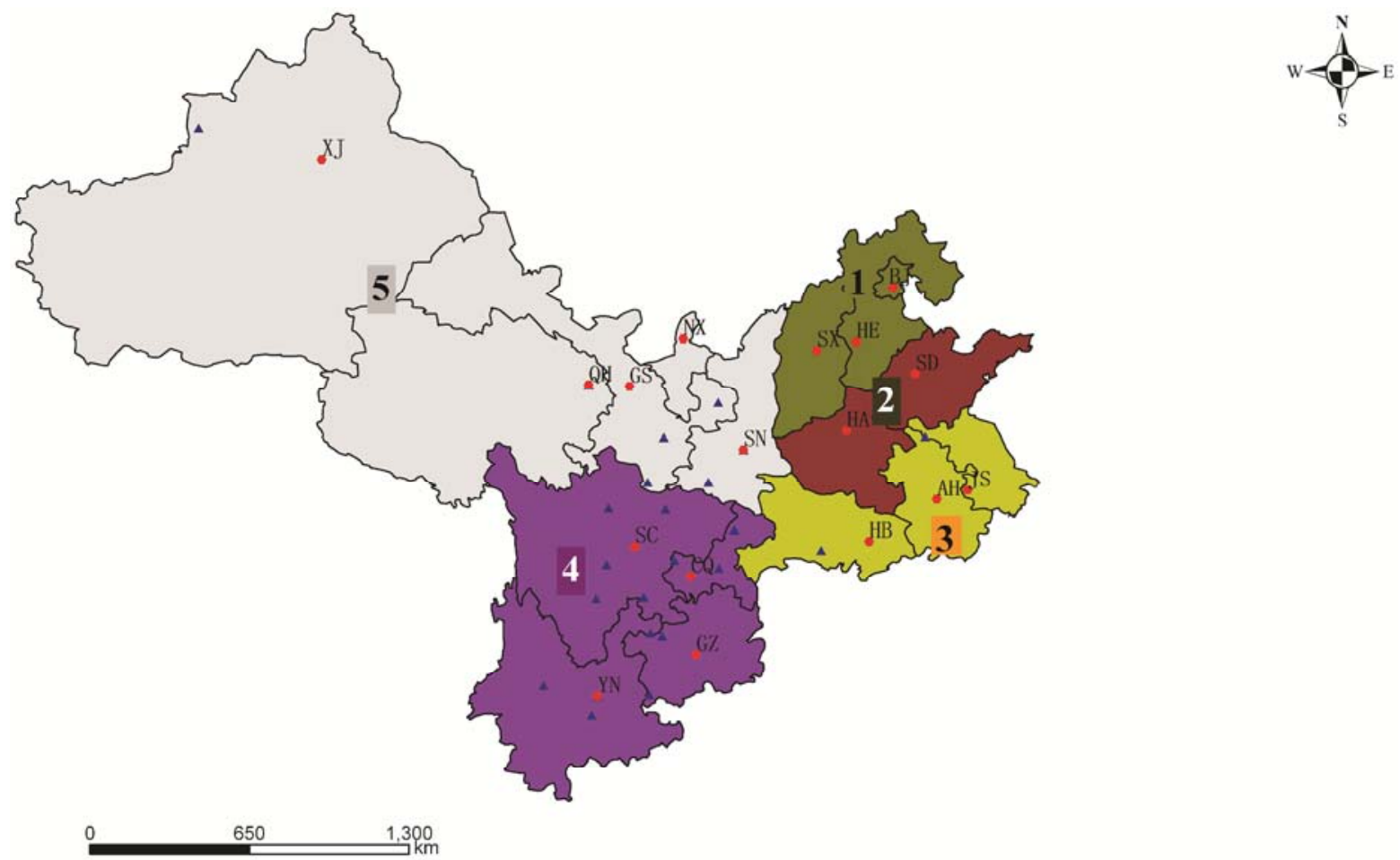

Fig. 1. Agroecological areas for Puccinia triticina in China where leaf rust samples were collected: area 1, mixed wheat types but primarily winter wheat; areas 2 and 3 , mixed wheat types but primarily facultative habit (winter or spring); area 4, mostly northern-adapted facultative wheat and southern-adapted spring wheat; and area 5 , mixed wheat types but primarily winter habit. Blue triangles show trap nursery sites and red dots indicate the provincial capitals. Area 1 , North China: BJ = Beijing city, HE = Hebei province, SX = Shanxi province; area 2, Huang-Huai-Hai regions: SD = Shandong province, HA = Henan province; area 3, Yangtze River valley: HB = Hubei province, JS = Jiangsu province, $\mathrm{AH}=$ Anhui province; area 4, Southwest China: $\mathrm{SC}=$ Sichuan province, $\mathrm{GZ}=$ Guizhou province, $\mathrm{YN}=\mathrm{Yunnan}$ province, $\mathrm{CQ}=\mathrm{Chongqing}$ city; and area 5 , Northwest China: $\mathrm{SN}=$ Shaanxi province, $\mathrm{GS}=$ Gansu province, $\mathrm{QH}=$ Qinghai province, $\mathrm{NX}=$ Ningxia autonomous region, $\mathrm{XJ}=\mathrm{Xinjiang}$ Uygur Autonomous Region. 
data from the larger sample to answer the question, "How many races would have been found in a smaller sample from that region?". If $n$ individuals composed the sample in the less-sampled region, rarefaction takes hypothetical subsamples of $n$ individuals from the more-sampled region and calculates the average number of races in such subsamples. This average can be compared with the number of races actually found in the less-sampled region. (The method computes a variance and standard deviation to facilitate interpretation of significant differences.)

Because sample sizes varied greatly, from 18 in 2002 to 158 in 2006 , the diversity in a subsample of 18 isolates (Table $1, \mathrm{Sub}_{18}$ ) and that in a subsample of 35 isolates (Table 2, Sub ${ }_{35}$ ) was recalculated by the rarefaction calculator to allow comparison of diversity in Chinese collections from different years at the same scale. In theory, any size of subsample could be chosen (i.e., $n=18,35$, 126 , and so on) but, normally, the smallest sample size of all the collections is used. In 2005, 126 Chinese isolates were tested for virulence profiles and 30 races were identified. In the United States in 2005, $797 \mathrm{Lr}$ single-uredinial isolates were tested and 72 virulence phenotypes (given in five letters, such as "BBBDB") of $P$. triticina were found. The same 12 Thatcher lines were used for race identification in China and the United States; thus, considering only the first three letters, such as "BBB," 46 virulence phenotypes were detected in 2005 in the United States. The Sub ${ }_{126}$ variable was computed to allow valid comparison of $P$. triticina virulence diversity in the sample of 126 isolates in China and the sample of 797 isolates in the United States.

The Statistical Analysis System (SAS edition 8.10e;SAS Institute) was used for calculating the $\chi^{2}$ statistic.

\section{Results}

Dynamics of races. In total, 613 single-uredinial isolates from the different wheat-growing areas of 16 provinces were tested for virulence, with 56 isolates in 2000, 59 in 2001, 18 in 2002, 53 in 2003, 143 in 2004, 126 in 2005, and 158 in 2006. In total, 79 races of $P$. triticina were detected in China among the 613 single-uredinial isolates. Predominant races were PHT at $23.7 \%$, THT at $14.7 \%$, $\mathrm{PHJ}$ at $11.4 \%$, THJ at $4.2 \%$, PCG at $4.1 \%$, and seven other races for which virulence frequencies were between 1.6 and $2.6 \%$ (Table 3 ). The virulence formulae of the 12 races with frequency greater than $1 \%$, averaging across areas, are listed in Table 3 . The change in frequency of five dominant races with frequencies more than $4 \%$ is shown in Figure 2. The most common races, PHT and THT, decreased in frequency but also fluctuated from year to year (Fig. 2). The frequency of PHT was $25.0 \%$ in 2000 , increased to $33.3 \%$ in 2002 , declined to $24.5 \%$ in 2004 , increased to $34.9 \%$ in 2005 , and dramatically decreased to $10.8 \%$ in 2006 . The frequency of race THT dropped from $41.1 \%$ in 2000 to $3.2 \%$ in 2006 but fluctuated in between. The frequency of PCG stood at 2 to $7 \%$, except when it was not detected in 2001 and 2002.

Distribution of races. Five races (PHT, THT, PHJ, THJ, and PCG) were detected in all five regions and, together, they made up $58.1 \%$ of all isolates during 2000 to 2006 (Table 3). In north China (area 1), 20 races were found among the 74 single-uredinial isolates tested. Races PHT (21.6\%), THT (20.3\%), and PHJ (14.9\%) were the three most common races in this area. In the Huang-HuaiHai regions (area 2), five races accounted for 120 of 177 isolates from this area: PHT (23.2\%), THT (20.3\%), PHJ (9.6\%), THJ $(8.5 \%)$, and THD (6.2\%). In the Yangtze River Valley (area 3), 11 races were found among the 35 isolates tested; PHT (31.4\%), THT (25.7\%), PHJ (11.4\%), and PHD (8.6\%) were the 4 most common races. In the southwest provinces (area 4), PHT (19.3), THT (7.2\%), PHJ (13.0\%), PCG (6.3\%), PCR (4.8\%), and DHJ (4.8\%) accounted for more than $50 \%$ of the isolates tested. In the northwest provinces (area 5), 36 races were found among 120 singleuredinial isolates tested; PHT (30.8\%), THT (12.5), PHJ (9.2\%), and FHT $(8.3 \%)$ were the 4 dominant races. Among regions, $\chi^{2}$ tests indicated significant differences in the distribution of $P$. triticina races $\left(\chi^{2}=459.7, \mathrm{DF}=312, P<0.001\right)$, especially for PHT, THJ, and PHJ $\left(\chi^{2}=16.5, \mathrm{DF}=8, P=0.0361\right)$.

Table 1. Chao-1 estimator $\left(S^{*} 1\right)$ measures the phenotypic diversity and richness for Puccinia triticina populations in China from 2000 to 2006

\begin{tabular}{|c|c|c|c|c|c|c|c|c|}
\hline \multirow[b]{2}{*}{ Population $^{b}$} & \multicolumn{8}{|c|}{ Year (number of isolates) ${ }^{\mathrm{a}}$} \\
\hline & $2000(n=56)$ & $2001(n=59)$ & $2002(n=18)$ & $2003(n=53)$ & $2004(n=143)$ & 2005-C $(n=126)$ & 2005-U $(n=797)$ & $2006(n=158)$ \\
\hline$\overline{S^{*} 1}$ & 46.2 & 19.0 & 15.3 & 61.3 & 37.3 & 58.1 & 46.4 & 68.8 \\
\hline$S d$ & 16.2 & 8.3 & 5.9 & 24.2 & 5.7 & 15.1 & 0.7 & 12.4 \\
\hline$S u b_{18}$ & 7.8 & 6.7 & 9.0 & 9.3 & 9.9 & 9.6 & 11.5 & 13.0 \\
\hline$S d_{18}^{18}$ & 1.6 & 1.2 & 0 & 1.5 & 1.7 & 1.7 & 1.6 & 1.6 \\
\hline$S u b_{126}$ & $\ldots$ & $\ldots$ & $\ldots$ & $\ldots$ & $\ldots$ & 30 & 29.4 & $\ldots$ \\
\hline$S d_{126}$ & $\ldots$ & $\ldots$ & $\ldots$ & $\ldots$ & $\ldots$ & 0.0 & 2.4 & $\ldots$ \\
\hline
\end{tabular}

${ }^{a}$ In 2005, 2005-C indicates isolates in China and 2005-U indicates isolates in the United States.

${ }^{b}$ The Chao-1 estimator of phenotypic diversity is calculated as $S^{*} 1=S_{o b s}+\left(a^{2} / 2 b\right)$, where $S_{o b s}$ is the number of races observed, $a$ is the number of races observed just once, and $b$ is the number of races observed just twice. Sd (standard deviation of $\left.S^{*} 1\right)=b\left[(a /[4 b])^{4}+(a / b)^{3}+(a /[2 b])^{2}\right.$. Sub $b_{18}$ means the average number of races in annual collections when sample sizes $>18$ were recalculated at the 18 -isolate scale by rarefaction. $S u b_{18}$ allows comparison of the richness of $P$. triticina races among years. $S d_{18}=$ standard deviation of races. $S u b_{126}=$ recalculation by rarefaction of the number of U.S. and Chinese races in 2005 as if sample sizes in both countries had been $126 . S d_{126}=$ standard deviation of races.

Table 2. Chao-1 estimator $\left(S^{*} 1\right)$ of the phenotypic diversity and richness of Puccinia triticina populations from five geographical areas in China from 2000 to 2006

\begin{tabular}{lccccc}
\hline & \multicolumn{5}{c}{ Area $($ number of races) } \\
\cline { 2 - 6 } Population $^{\mathbf{b}}$ & $\mathbf{1}(\boldsymbol{n}=\mathbf{2 0})$ & $\mathbf{2}(\boldsymbol{n}=\mathbf{3 3})$ & $\mathbf{3}(\boldsymbol{n = 1 1 )}$ & $\mathbf{4}(\boldsymbol{n}=\mathbf{3 6})$ & $\mathbf{5}(\boldsymbol{n}=\mathbf{5 0})$ \\
\hline$S^{*} 1$ & 80.5 & 105.3 & 29.0 & 67.5 & 14.4 \\
$S d$ & 37.1 & 36.1 & 15.1 & 16.2 & 17.3 \\
$S u b_{35}$ & 13.4 & 14.1 & 11 & 2.2 & 18.3 \\
$S d_{35}$ & 1.6 & 2.0 & 0 & 2.2 & \\
\hline
\end{tabular}

a Area 1: $\mathrm{BJ}=$ Beijing city, $\mathrm{HE}=$ Hebei province, $\mathrm{SX}=$ Shanxi province; area 2: $\mathrm{SD}=$ Shandong province, $\mathrm{HA}=$ Henan province; area 3: HB = Hubei province, $\mathrm{JS}=$ Jiangsu province, $\mathrm{AH}=$ Anhui province; area 4: $\mathrm{SC}=$ Sichuan province, $\mathrm{GZ}=$ Guizhou province, $\mathrm{YN}=\mathrm{Yunnan}$ province, $\mathrm{CQ}=\mathrm{Chongqing}$ city; area 5: $\mathrm{SN}=$ Shaanxi province, $\mathrm{GS}=$ Gansu province, $\mathrm{QH}=$ Qinghai province, $\mathrm{NX}=$ Ningxia autonomous region, $\mathrm{XJ}=\mathrm{Xinjiang}$ Uygur Autonomous Region. Total number of races $=79$.

${ }^{\text {b }}$ The Chao-1 estimator of phenotypic diversity is calculated as $S^{*} 1=S_{o b s}+\left(a^{2} / 2 b\right)$, where $S_{o b s}$ is the number of races observed, $a$ is the number of races observed just once, and $b$ is the number of races observed just twice. Sd (standard deviation of $\left.S^{*} 1\right)=b\left[(a /[4 b])^{4}+(a / b)^{3}+(a /[2 b])^{2}\right.$. Sub $b_{35}=a v e r a g e$ number of races in regional collections with sample size $>35$, recalculated at the 35 -isolate scale by rarefaction. $S u b_{35}$ allows comparison of the richness of P. triticina races among regions. $S d_{35}=$ standard deviation of races. 
Frequencies of virulence genes. The 613 isolates of $P$. triticina were tested for virulence to 28 known $L r$ genes or gene combinations (Table 4). Frequencies of virulence differed among the regional populations of $P$. triticina in China during the past 7 years. Less than $30 \%$ of all isolates were virulent to $\operatorname{Lr} 2 a, \operatorname{Lr} 9, \operatorname{Lr} 15$, $L r 19, L r 24, L r 25, L r 28$, or $L r 29$. Less than $3 \%$ of all isolates were virulent to $\operatorname{Lr} 9, \operatorname{Lr} 19, \operatorname{Lr} 24, \operatorname{Lr} 25, \operatorname{Lr} 28$, or $\operatorname{Lr} 29$, whereas virulence to $L r 2 c, L r 3, L r 14 a, L r 26$, or $L r 33$ was common throughout the Chinese areas surveyed (frequencies of more than 90\%). Virulences to $L r 3 \mathrm{ka}$ and $L r 20$ were also found with frequency of 55.8 and $36.2 \%$, respectively, in the total population. The weighted average frequency across years of virulence to $L r 2 b, L r 3 b g, L r 10$, $L r 14 b, L r 18, L r 23, L r 27+31,10, \operatorname{Lr} 30$, and $L r 32$ was high (62.0 to $89.5 \%)$. The results suggest that the corresponding leaf rust resistance genes $\operatorname{Lr} 9, \operatorname{Lr} 19, \operatorname{Lr} 24, \operatorname{Lr} 25, \operatorname{Lr} 28$, and $L r 29$ are effective against the wheat leaf rust population in China at present, which is basically consistent with the results of 1997 to 1999, except for the decreasing frequency of virulence to $\operatorname{Lr} 25$ (30). Virulence to $\operatorname{Lr} 2 a$, $L r 3 k a, L r 11$, and Lr30 is still common, even though it may have declined in recent years (Table 4$)$. The frequency of virulence to $L r 1, L r 2 c, L r 3, L r 16, L r 17$, and $L r 26$ was high (73.6 to $100 \%)$ during 2000 to 2006 but fluctuated from year to year, which indicated that wheat cultivars with those genes were widely planted in the Chinese wheat-growing area. The weighted average frequency of virulence to $L r 1, L r 2 c, L r 3, L r 16, L r 17$, and $L r 26$ was 67.0, 94.4, 74.0, 96.6, and 98.2\%, respectively during 1992 to 1996 in China (3) and 87.1, 98.0, 91.0, 82.1, and 85.0\%, respectively, during 2000 to 2006. Among the 613 isolates tested, virulence to $\operatorname{Lr} 9$ was only found once in Yunnan province in 2005. Nine isolates were virulent to Lr19 (one in Henan in 2007, two in Shandong in 2003 and 2007, one in Hubei in 2007, two in Gansu in 2007, two in Yunnan in 2003 and 2007, and one in Sichuan province in 2007). Two isolates showed virulence to Lr24; both were found in 2002, one in Henan and the other in Xinjiang. In all, 2, 5, and 13 isolates had virulence to $L r 25, L r 28$, and $L r 29$, respectively. Combined virulence to Lr24 and Lr29 was found only once (in Emin county, Xinjiang Uygur Autonomous Region in 2002).

Diversity of races and virulence. The $P$. triticina population in China was highly diverse, with 79 races being detected in samples collected from 2000 to 2006 . In general, P. triticina populations sampled from 2000 to 2006 showed a tendency toward increasing race diversity (Fig. 3; Table 1), which was compared at the same scale of 18 samples by rarefaction calculator (11). The Chao- 1 estimator fluctuated between years that showed different diversities (Fig. 3; Table 1). The P. triticina population in Huang-Huai-Hai regions of China (area 2) was the most diverse of the population regions according to the Chao-1 estimator, whereas those in northwest China (area 5) and in north China (area 1) displayed less diversity. The diversity in the Yangtze River Valley was lowest compared with other regions (Table 2).

\section{Discussion}

The $P$. triticina populations in China appeared to be somewhat stable among regions but changed on an annual basis with respect to virulence. The frequency of PHT remained basically stable from 2000 to 2005 but dropped in 2006. The frequency of THT displayed a decreasing tendency from 2000 to 2006. Both races are virulent to $L r 1, L r 2 c, L r 3, L r 11, L r 16, L r 17, L r 26, L r 3 k a$, or $L r 30$ and are avirulent to $\operatorname{Lr} 9$ and $L r 24$. In 1997 to 1999 (30), THT was detected at higher average frequency $(22.1 \%)$ than from 2000 to 2006 (14.7\%) whereas the frequency of PHT appeared fairly stable between the two sampling periods (20.8 to $23.7 \%$ ). These two races were distributed widely throughout China, and were the most common races of $P$. triticina in China during and prior to the pe-

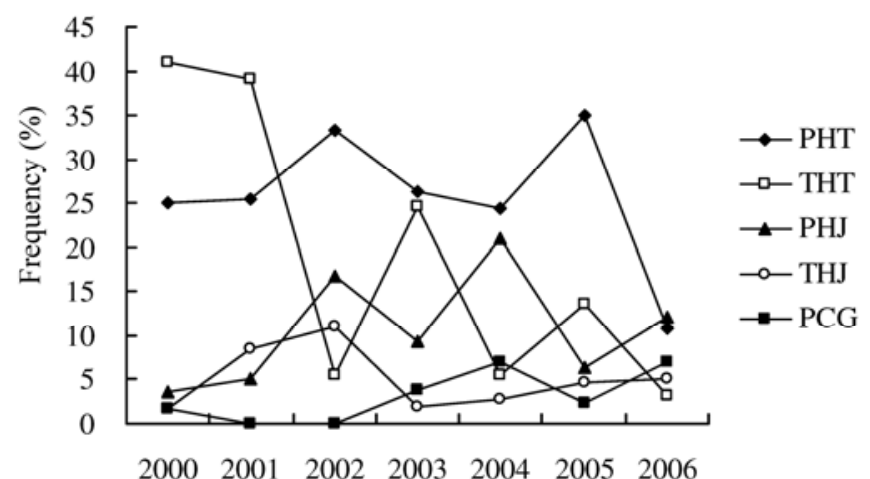

Fig. 2. Frequency changes of predominant races of Puccinia triticina on wheat in China during 2000 to 2006.

Table 3. Distribution and frequencies of predominant races of Puccinia triticina from samples collected in Chinese wheat fields in 2000 to $2006^{\mathrm{a}}$

\begin{tabular}{|c|c|c|c|c|c|c|c|c|c|c|c|c|c|}
\hline \multirow[b]{2}{*}{ Races } & \multirow[b]{2}{*}{ Avirulence/virulence formulae } & \multicolumn{2}{|c|}{$\begin{array}{l}\text { North } \\
\text { China }^{b}\end{array}$} & \multicolumn{2}{|c|}{$\begin{array}{l}\text { Huang-Huai- } \\
\text { Hai regions }\end{array}$} & \multicolumn{2}{|c|}{$\begin{array}{c}\text { Yangtze River } \\
\text { valley }^{d}\end{array}$} & \multicolumn{2}{|c|}{$\begin{array}{c}\text { Southwest } \\
\text { China }^{\mathrm{e}}\end{array}$} & \multicolumn{2}{|c|}{$\begin{array}{l}\text { Northwest } \\
\text { China }^{\mathrm{f}}\end{array}$} & \multicolumn{2}{|c|}{ Totalg } \\
\hline & & $N$ & $\%$ & $N$ & $\%$ & $N$ & $\%$ & $N$ & $\%$ & $N$ & $\%$ & $N$ & $\%$ \\
\hline PHT & $2 a, 9,24 / 1,2 c, 3,16,26,3 \mathrm{ka}, 11,17,30$ & 16 & 21.6 & 41 & 23.2 & 11 & 31.4 & 40 & 19.3 & 37 & 30.8 & 145 & 23.7 \\
\hline THT & $9,24 / 1,2 a, 2 c, 3,16,26,3 \mathrm{ka}, 11,17,30$ & 15 & 20.3 & 36 & 20.3 & 9 & 25.7 & 15 & 7.3 & 15 & 12.5 & 90 & 14.7 \\
\hline PHJ & $2 a, 3 k a, 9,24,30 / 1,2 c, 3,16,26,11,17$ & 11 & 14.9 & 17 & 9.6 & 4 & 11.4 & 27 & 13.0 & 11 & 9.2 & 70 & 11.4 \\
\hline THJ & $9,24,3 \mathrm{ka}, 30 / 1,2 a, 2 c, 3,16,26,11,17$ & 5 & 6.8 & 15 & 8.5 & 1 & 2.9 & 3 & 1.5 & 2 & 1.7 & 26 & 4.2 \\
\hline PCG & $2 a, 9,16,24,3 \mathrm{ka}, 17,30 / 1,2 c, 3,11,26$ & 3 & 4.1 & 6 & 3.4 & 0 & 0.0 & 13 & 6.3 & 3 & 2.5 & 25 & 4.1 \\
\hline PCR & $2 a, 9,16,17,24 / 1,2 c, 3,26,3 \mathrm{ka}, 11,30$ & 1 & 1.4 & 3 & 1.7 & 1 & 2.9 & 10 & 4.8 & 1 & 0.8 & 16 & 2.6 \\
\hline PHD & $2 a, 3 k a, 9,11,24,30 / 1,2 c, 3,16,17,26$ & 1 & 1.4 & 6 & 3.4 & 3 & 8.6 & 5 & 2.4 & 1 & 0.8 & 16 & 2.6 \\
\hline THD & $3 k a, 11,9,24,30 / 1,2 a, 2 c, 3,16,26,17$ & 3 & 4.1 & 11 & 6.2 & 0 & 0.0 & 0 & 0.0 & 2 & 1.7 & 16 & 2.6 \\
\hline FHT & $1,2 a, 9,24 / 2 c, 3,3 k a, 11,16,17,26,30$ & 0 & 0.0 & 3 & 1.7 & 0 & 0.0 & 3 & 1.5 & 10 & 8.3 & 16 & 2.6 \\
\hline DHJ & $1,2 a, 3,9,24,3 \mathrm{ka}, 30 / 2 c, 16,17,11,26$ & 0 & 0.0 & 0 & 0.0 & 0 & 0.0 & 10 & 4.8 & 2 & 1.7 & 12 & 2.0 \\
\hline THP & $9,24,11 / 1,2 a, 2 c, 3,16,26,3 \mathrm{ka}, 17,30$ & 0 & 0.0 & 5 & 2.8 & 1 & 2.9 & 1 & 0.5 & 3 & 2.5 & 10 & 1.6 \\
\hline NHJ & $2 a, 3,9,24,3 \mathrm{ka}, 30 / 1,2 \mathrm{c}, 16,17,11,26$ & 0 & 0.0 & 1 & 0.6 & 0 & 0.0 & 8 & 3.9 & 1 & 0.8 & 10 & 1.6 \\
\hline Other ${ }^{\mathrm{h}}$ & $\ldots$ & 19 & 25.7 & 33 & 18.6 & 5 & 14.3 & 72 & 34.8 & 32 & 26.7 & 161 & 26.3 \\
\hline Total $^{\mathrm{i}}$ & $\ldots$ & 74 & $\ldots$ & 177 & $\ldots$ & 35 & $\ldots$ & 207 & $\ldots$ & 120 & $\ldots$ & 613 & $\ldots$ \\
\hline
\end{tabular}

${ }^{a}$ Data are numbers and percentages of isolates.

b North China (area 1): BJ = Beijing city, HE = Hebei province, $\mathrm{SX}=$ Shanxi province.

${ }^{\mathrm{c}}$ Huang-Huai-Hai regions (area 2): $\mathrm{SD}=$ Shandong province, $\mathrm{HA}=$ Henan province.

d Yangtze River valley (area 3): $\mathrm{HB}=$ Hubei province, $\mathrm{JS}=$ Jiangsu province, $\mathrm{AH}=$ Anhui province.

e Southwest China (area 4): $\mathrm{SC}=$ Sichuan province, $\mathrm{GZ}=$ Guizhou province, $\mathrm{YN}=$ Yunnan province, $\mathrm{CQ}=\mathrm{Chongqing}$ city.

${ }^{\mathrm{f}}$ Northwest China (area 5): $\mathrm{SN}=$ Shaanxi province, $\mathrm{GS}=$ Gansu province, $\mathrm{QH}=$ Qinghai province, $\mathrm{NX}=$ Ningxia autonomous region, $\mathrm{XJ}=\mathrm{Xinjiang}$ Uygur Autonomous Region.

$\mathrm{g}$ Weighted average frequencies during 2000 to 2006.

${ }^{\mathrm{h}}$ Races were detected no more than six times ( $<1 \%$ frequency) within the 7 years.

i Total isolates for test. 
riod of this study. PHT and THT occurred at very similar frequency (between 20.3 and 23.2\%) in north China (area 1) and the HuangHuai-Hai region (area 2) but occurred at variable frequency in the other wheat-growing areas; for example, 30.8 to $12.5 \%$ in northwest China (area 5), 19.3 to $7.3 \%$ in southwest China (area 4), and 31.4 to $25.7 \%$ in the Yangtze River Valley (area 3) during 2000 to 2006 (Table 3). This probably reflects the selective effects of wheat cultivars with different leaf rust resistance genes in the different wheat-growing areas.

The Chinese $P$. triticina population exhibited great diversity with a complex virulence structure, which could be mostly ascribed to the diversity of wheat genotypes planted in various wheat-growing regions. In total, 79 races were detected during the period 2000 to 2006. Since the 1990s, wheat breeding for rust resistance, with emphasis on the development of slow-rusting or durably resistant cultivars, has been a priority in parts of China such as Sichuan, Gansu, Henan, Shaanxi, and Yunnan provinces (12). Cultivars with different resistance genes or gene combinations would be expected to select different matching virulences in the pathogen. However, despite a large number of $P$. triticina races being detected across the country over the 7-year period, only a few races such as PHT, THT, and PHJ appeared with relatively high frequencies, suggesting that the situation of the most common Chinese wheat cultivars having simple resistance to leaf rust has remained unchanged (21,33).

In previous reports $(21,42), 16$ named genes $(L r 1, L r 2 a, L r 3 b g$, Lr3ka, Lr10, Lr13, Lr14a, Lr16, Lr17a, Lr18, Lr20, Lr23, Lr24, Lr26, Lr34, and LrZH84) were postulated to be present in 265 Chinese wheat cultivars but $\operatorname{Lr} 26$ and $\operatorname{Lr} 16$ were most frequently detected, with frequencies of 47.2 and $20.4 \%$, respectively. Most of the 16 genes were ineffective against the Chinese $P$. triticina population. The high frequency of virulence to $L r 26$ was due to the widespread use of the 1BL.1RS translocation bearing $Y r 9$ and $L r 26$ in Chinese breeding programs since the 1970s $(21,33)$. For example, 'Aikang 58' (bearing Lr26) was a popular commercial cultivar in the Huang-Huai-Hai region, planted on more than 0.5 million ha after its release in 2005. 'Zhengmai 9023', which carried Lr16 and an unknown $L r$ gene, was released at Henan and in the Yangtze
River Valley (at Hubei in 2001 and Jiangsu and Anhui in 2002). Since 2003, Zhengmai 9023 has been planted every year and has become the predominant commercial cultivar in the Huang-HuaiHai region, with a cropped area of more than 2 million ha in 2006. Since the 1980s, 'Fan 6' and its derivatives with the resistance gene Lr16 have become the leading cultivars in the southwestern regions and the mid-valley of the Yangtze River. Those cultivars provided favorable conditions for the directional selection of virulence in Chinese $P$. triticina populations, and at least partially accounted for the high frequency of virulence to $L r 26$ and Lrl6.

The frequency of $L r l$ in 265 wheat cultivars or lines tested was about $7.6 \%(21,33)$, and $33.9 \%$ by polymerase chain reaction (PCR) detection using $L r l$-specific primers in 116 Chinese-released cultivars (unpublished data), which probably accounts for the high frequency of virulence to $L r l$ in Chinese leaf rust populations. Other $\operatorname{Lr}$ genes such as $\operatorname{Lr} 9, \operatorname{Lr} 19$, and $\operatorname{Lr} 24$ are infrequently present in Chinese wheat cultivars, as detected by gene postulation and molecular methods $(21,33)$, which could explain the low virulence frequency of the matching virulences in the Chinese $P$. triticina population. Consequently, diversity of planted wheat cultivars

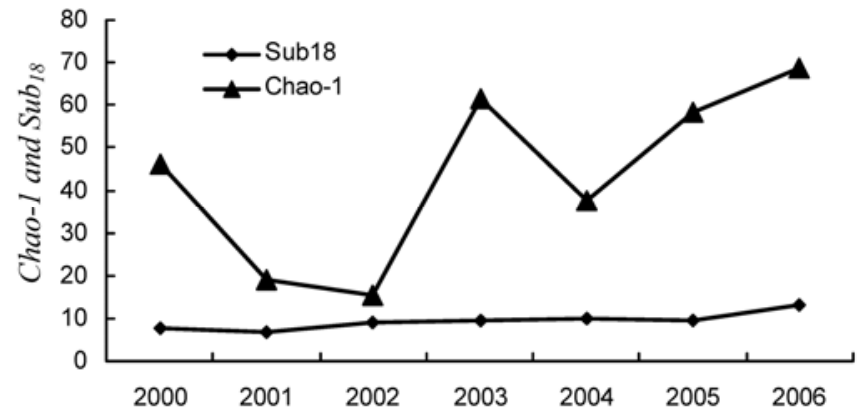

Fig. 3. Diversity and richness of the Puccinia triticina population in China from 2000 to 2006 indicated by the Chao-1 estimator $\left(S^{*} 1\right)$ and $S u b_{18}$. See the text for calculation of the Chao-1 estimator. $S u_{18}$ indicates the average richness of $P$. triticina races among samples with $\geq 18$ isolates calculated by rarefaction and using subsamples of 18 .

Table 4. Frequency of virulence to wheat leaf rust resistance genes among 613 Puccinia triticina isolates collected in China during 2000 to 2006

\begin{tabular}{|c|c|c|c|c|c|c|c|c|c|}
\hline \multirow[b]{2}{*}{ Testers } & \multirow[b]{2}{*}{$L r$ genes } & \multicolumn{8}{|c|}{ Frequency (\%) } \\
\hline & & 2000 & 2001 & 2002 & 2003 & 2004 & 2005 & 2006 & $\mathbf{F x} \mathbf{x}^{\mathbf{a}}$ \\
\hline TcLr1 & Lrl & 85.7 & 93.2 & 83.3 & 73.6 & 92.3 & 89.7 & 83.5 & 87.1 \\
\hline TcLr2a & $\operatorname{Lr} 2 a$ & 53.6 & 50.9 & 27.8 & 30.2 & 13.3 & 31.8 & 25.3 & 29.4 \\
\hline TcLr2b & $L r 2 b$ & 69.1 & 93.2 & 81.3 & 88.7 & 90.9 & 76.2 & 88.6 & 85.1 \\
\hline TcLr2c & $\operatorname{Lr} 2 c$ & 98.2 & 98.3 & 100.0 & 94.3 & 99.3 & 97.6 & 98.1 & 98.0 \\
\hline TcLr3 & Lr3 & 85.7 & 100.0 & 100.0 & 98.1 & 96.5 & 92.7 & 79.8 & 91.0 \\
\hline TcLr3bg & Lr3bg & 66.1 & 98.3 & 88.9 & 94.3 & 96.5 & 93.6 & 79.1 & 88.4 \\
\hline TcLr3ka & Lr3ka & 75.0 & 86.4 & 66.7 & 64.2 & 42.7 & 74.6 & 30.3 & 55.8 \\
\hline TcLr9 & $\operatorname{Lr} 9$ & 0.0 & 0.0 & 0.0 & 0.0 & 0.0 & 0.8 & 0.0 & 0.2 \\
\hline TcLr10 & Lr10 & 82.1 & 100.0 & 94.1 & 96.2 & 95.1 & 93.7 & 77.2 & 89.5 \\
\hline Hussar(W976) & $\operatorname{Lrl1}$ & 89.3 & 100.0 & 94.4 & 90.6 & 82.5 & 81.0 & 62.7 & 80.4 \\
\hline TcLr14a & $L r 14 a$ & 100.0 & 100.0 & 100.0 & 98.1 & 98.6 & 97.6 & 100.0 & 99.0 \\
\hline TcL14b & $L r 14 b$ & 92.7 & 98.3 & 100.0 & 86.5 & 84.6 & 82.5 & 89.2 & 88.1 \\
\hline TcLr15 & $\operatorname{Lr} 15$ & 23.6 & 10.2 & 33.3 & 24.5 & 43.4 & 19.8 & 25.3 & 27.0 \\
\hline TcLr16 & Lr16 & 91.1 & 86.4 & 94.4 & 84.9 & 78.3 & 91.3 & 70.9 & 82.1 \\
\hline TcLr17 & Lr17 & 92.9 & 89.8 & 100.0 & 88.7 & 81.1 & 93.7 & 74.1 & 85.0 \\
\hline TcLr18 & $\operatorname{Lr} 18$ & 68.5 & 94.9 & 66.7 & 60.4 & 48.3 & 76.2 & 48.7 & 62.0 \\
\hline TcLr19 & Lr19 & 0.0 & 0.0 & 0.0 & 3.8 & 0.7 & 0.0 & 3.8 & 1.5 \\
\hline Thew(W203) & $\operatorname{Lr} 20$ & 41.8 & 56.9 & 60.0 & 48.1 & 26.6 & 20.6 & 41.8 & 36.2 \\
\hline TcLr23 & $\operatorname{Lr} 23$ & 53.6 & 89.7 & 77.8 & 60.4 & 75.5 & 90.5 & 20.3 & 62.4 \\
\hline TcLr24 & $\operatorname{Lr} 24$ & 0.0 & 0.0 & 11.1 & 0.0 & 0.0 & 0.0 & 0.0 & 0.3 \\
\hline Transec(Awned) & $\operatorname{Lr} 25$ & 0.0 & 1.7 & 0.0 & 1.9 & 0.0 & 0.0 & 0.0 & 0.3 \\
\hline TcLr26 & $\operatorname{Lr} 26$ & 89.3 & 96.6 & 100.0 & 94.3 & 98.6 & 98.4 & 95.6 & 96.4 \\
\hline Gatcher & $L r 27+31,10$ & 30.4 & 81.0 & 92.9 & 85.7 & 88.1 & 97.6 & 93.6 & 85.4 \\
\hline CM2D-2M & $\operatorname{Lr} 28$ & 3.6 & 0.0 & 0.0 & 0.0 & 0.0 & 0.8 & 1.3 & 0.8 \\
\hline TcLr29 & $\operatorname{Lr} 29$ & 3.6 & 3.4 & 16.7 & 9.4 & 0.0 & 0.8 & 0.6 & 2.3 \\
\hline TcLr30 & $\operatorname{Lr} 30$ & 71.4 & 86.4 & 66.7 & 67.9 & 42.7 & 73.0 & 31.0 & 55.6 \\
\hline TcLr32 & Lr32 & 58.9 & 100.0 & 83.3 & 71.7 & 54.6 & 76.2 & 48.7 & 64.6 \\
\hline TcLr33 & Lr33 & 85.7 & 93.2 & 83.3 & 73.6 & 92.3 & 89.7 & 83.5 & 87.1 \\
\hline
\end{tabular}

a Weighted average in the 7 years. 
with different $L r$ genes probably is the main reason that the Chinese $P$. triticina population has maintained great diversity and relative stability for races and virulences.

Distribution patterns of $P$. triticina races and virulences and the diversity of populations differ among regions of China, suggesting that Chinese $P$. triticina populations may be isolated from other global populations of the fungus. Comparison of Chao-1 estimators within China and between China and the United States indicated that the $P$. triticina populations in the two countries showed substantial differences in virulence and diversity. However, the richness or evenness of races seemed similarly distributed in both countries by $\mathrm{Sub}_{126}$ (See Materials and Methods and Table 1). There were 30 races in China in 2005, with $29.4 \pm 2.4$ races for $S u b_{126}$. In contrast, races TDB, MLD, MFP, MCB, TNR, and TFB were the most common in the United States in 2005 and 2007 $(19,20)$. Moreover, the frequencies of virulence to $L r$ genes differed between the two countries. Virulence to Lr3ka, Lr11, Lrl6, $\operatorname{Lr} 18, \operatorname{Lr} 26$, and $\operatorname{Lr} 30$ was, in each case, over $55.6 \%$ in China but below $34.6 \%$ in the United States; in particular, the frequency of virulence to Lrl6 was only $8.7 \%$ in the United States in 2006 but reached $82.1 \%$ in China during the period 2000 to 2006. Differences in virulence to $\operatorname{Lr} 9, \operatorname{Lr} 24$, and $\operatorname{Lr} 28$ were also found, with frequencies of $<1 \%$ in China; whereas, in the United States, virulence to $\operatorname{Lr} 9$ was 15.3 and $12.9 \%$, to $\operatorname{Lr} 24$ was 56.1 and $72.4 \%$, and to $\operatorname{Lr} 28$ was 70.3 and $66.5 \%$ in 2005 and 2007 , respectively.

In Mexico, races TBD/TM (virulent to $L r 10, L r 17$, and $L r 27+31$ but avirulent to $L r 23$ and $L r 26$ ) and TCB/TD (virulent to $L r 23$ and $L r 26$ but avirulent on $L r 10, L r 17$, and $L r 27+31$ ) were the most common before 1994 (32). A new race, BBG/BN, with high virulence to durum wheat, was detected in northwestern Mexico in 2001 (34). An annual survey of $P$. triticina races in South America indicated that race MCP-10, with additional virulence on $\operatorname{Lr} 10$, and races MDR-10, MDR-20, and MFP-20 were present in high frequencies during 2004 to 2007 (10). Mesterházy et al. (28) conducted a European virulence survey for $P$. triticina, which included France, Germany, Italy, Czech Republic, Slovakia, Great Britain, Spain, Hungary, Poland, Bulgaria, Romania, and Switzerland, and identified 105 races in a total of 2,608 isolates using 15 near-isogenic Thatcher lines. Virulence to Lr12, Lr13, Lr22a, and Lr37 varied among locations but no virulence was found to $\operatorname{Lr} 9, \operatorname{Lr} 19$, and $L r 35$. One leaf rust survey in Iran from 2002 to 2004 indicated virulence to $\operatorname{Lr} 24$, and no virulence to $\operatorname{Lr} 18, \operatorname{Lr} 34, \operatorname{Lr} 35, \operatorname{Lr} 36$, or Lr37 was detected (1). Races CBHN (9.2\%), DDPR (10.8\%), FNMQ (7.5\%), and JNDC (10.8\%) were detected to be most common in Tunisia during 2005 to 2007 (29). Differing climatic conditions and wheat planting systems, particularly differences in wheat genotypes planted in various areas, are the main reasons for the geographic differences in $P$. triticina.

\section{Acknowledgments}

Financial support was provided by the Ministry of Science and Technology, P. R. China (grant number 2011CB100403 and 2010CB951503); Ministry of Agriculture, P. R. China (grant number 200903035); and National Natural Scientific Foundation of China (number 30800709). We thank X. Chen, United States Department of Agriculture-Agricultural Research Service and Washington State University, and R. F. Park, Plant Breeding Institute at University of Sydney, for their critical and conscientious review of the previous version of this article prior to submission; and anonymous reviewers and the senior editor for their efforts, and for the improvements made possible by their critical reviews.

\section{Literature Cited}

1. Afshari, F., Torabi, M., Kia, S., Dadrezaei, S., Safavi, S., Chaichi, M., Khiavi, H. K., Zakeri, A., Kamangar, S. B., and Nasrollahi, M. 2006. Monitoring of virulence factors of Puccinia triticina Eriksson, the causal agent of wheat leaf rust in Iran during 2002-2004. Seed Plant Improv. J. 21:485-496.

2. Chao, A. 1984. Nonparametric estimation of the number of classes in a population. Scand. J. Stat. 11:265-270.

3. Chen, W. Q., Hu, C. C., and Zhang, S. X. 1993. Analysis of virulence genes of Puccinia recondita f. sp. tritici population in China. Sci. Agric. Sin. 26:17-23. (In Chinese with English abstract)

4. Chen, W. Q., Qin, Q. M., Chen, Y. L., and Yan, S. B. 1998. Virulence dynamics of Puccinia recondita f. sp. tritici in China during 1992-1996. Acta Phytopathol. Sin. 28:101-106. (In Chinese with English abstract)

5. Chen, W. Q., Wu, L. R., Liu, T. G., Xu, S. C., Jin, S. L., Peng, Y. L., and
Wang, B. T. 2009. Race dynamics, diversity, and virulence evolution in Puccinia striiformis f. sp. tritici, the causal agent of wheat stripe rust in China from 2003 to 2007. Plant Dis. 93:1093-1101.

6. Chen, W. Q., Yan, S. B., Hu, C. C., and Xie, S. X. 1994. Physiologic race and pathogenicity of Puccinia recondita f. sp. tritici in China during 1990-1993. Acta Phytophylac. Sin. 21:289-295. (In Chinese with English abstract.)

7. Chen, X. M. 2005. Epidemiology and control of stripe rust [Puccinia striiformis f. sp. tritici] on wheat. Can. J. Plant Pathol. 27:314-337.

8. Colwell, R. K., and Coddington, J. A. 1994. Estimating terrestrial biodiversity through extrapolation. Phil. Trans. R. Soc. Lond. (Ser. B) 345:101-118.

9. Dyck, P. L., and Samborski, D. J. 1968. Genetics of resistance to leaf rust in the common wheat varieties Webster, Loros, Brevit, Carina, Malakof and Centenario. Can. J. Genet. Cytol. 10:7-17.

10. Germán, S., Barcellos, A., Chaves, M., Kohli, M., Campos, P., and de Viedma, L. 2007. The situation of common wheat rusts in the Southern Cone of America and perspectives for control. Aust. J. Agric. Res. 58:620630.

11. Grünwald, N. J., Goodwin, S. B., Milgroom, M. G., and Fry, W. E. 2003. Analysis of genotypic diversity data for populations of microorganisms. Phytopathology 93:738-746.

12. He, Z. H., Rajaram, S., Xin, Z. Y., and Huang, G. Z. 2001. A History of Wheat Breeding in China. CIMMYT, Mexico, D.F.

13. Hu, C. C., and Roelfs, A. P. 1985. The wheat rusts in the People's Republic of China. Cereal Rust Bull. 13:11-28.

14. Hu, C. C., and Roelfs, A. P.. 1989. Races and virulence of Puccinia recondita f. sp. tritici in China in 1986. Plant Dis. 73:499-501.

15. Johnson, T. 1956. Physiologic races of leaf rust of wheat in Canada 1931 to 1955. Can. J. Agric. Sci. 36:323-332.

16. Johnston, C. O., Caldwell, R. M., Compton, L. E., and Browder, L. E. 1968. Physiologic races of Puccinia recondita f. sp. tritici in the United States from 1926 through 1960. U. S. Dep. Agric. Tech. Bull. 1393:1-18.

17. Johnston, C. O., and Mains, E. E. 1932. Studies on physiologic specialization in Puccinia triticina. U. S. Dep. Agric. Tech. Bull. 313:1-22.

18. Kolmer, J. A. 1997. Virulence in Puccinia recondita f. sp. tritici isolates from Canada to genes for adult-plant resistance to wheat leaf rust. Plant Dis. 81:267-271.

19. Kolmer, J. A., Long, D. L., and Hughes, M. E. 2007. Physiologic specialization of Puccinia triticina on wheat in the United States in 2005. Plant Dis. 91:979-984.

20. Kolmer, J. A., Long, D. L., Hughes, M. E. 2009. Physiologic specialization of Puccinia triticina on wheat in the United States in 2007. Plant Dis. 93:538-544.

21. Li, Z. F., Xia, X. C., He, Z. H., Li, X., Zhang, L. J., Wang, H. Y., Meng, Q. F., Yang, W. X., Li, G. Q., and Liu, D. Q. 2010. Seedling and slow rusting resistance to leaf rust in Chinese wheat cultivars. Plant Dis. 94:45-53.

22. Line, R. F., and Chen, X. M. 1995. Successes in breeding for and managing durable resistance to wheat rusts. Plant Dis. 79:1254-1255.

23. Liu, Q. C., Tang, Y. L., and Liu, Q. J. 1995. Physiological races and virulent genes analysis of Puccinia recondita f. sp. tritici in Shandong province. Shandong Agric. Sci. 4:35-38. (In Chinese with English abstract.)

24. Long, D. L., and Kolmer, J. A. 1989. A north American system of nomenclature for Puccinia recondita f. sp. tritici. Phytopathology 79:525529.

25. McIntosh, R. A., and Brown, G. N. 1997. Anticipatory breeding for resistance to rust diseases in wheat. Annu. Rev. Phytopathol. 35:311-326.

26. McIntosh, R. A., Wellings, C. R., and Park, R. 1995. Wheat Rusts: An Atlas of Resistance Genes. Kluwer Academic Publishers, Dordrecht, The Netherlands and CSIRO Australia.

27. McIntosh, R. A., Yamazaki, Y., Devos, K. M., Dubcovsky, J., Rogers, J., and Appels, R. 2003. Catalogue of gene symbols for wheat. In: Tenth Int. Wheat Genet. Symp. N. E. Pogna, N. Romano, E. Pogna, and G. Galterio, eds. Instituto Sperimentale per la Cerealcoltura, Rome.

28. Mesterházy, Á., Bartoš, P., Goyeau, H., Niks, R. E., Csösz, M., Andersen, O., Casulli, F., Ittu, M., Jones, E., Manisterski, J., Manninger, K., Pasquini, M., Rubiales, D., Schachermayr, G., Strzembicha, A., Szunics, L., Todorova, M., Unger, O., Vanco, B., Vida, G., and Walther, U. 2000. European virulence survey for leaf rust in wheat. Agronomie 20:793-804.

29. Mosbahi, M., Yahyaoui, A., Sayar, R., Hajlaoui, M. R., Sakkouhi, L., and Daaloul, A. 2009. Virulence analysis of Puccinia recondita in Tunisia during the period 2005-2007. Tunis. J. Plant Prot. 4:111-120.

30. Qin, Q. M., and Chen, W. Q. 2000. Races and virulence of Puccinia recondita f. sp. tritici in China during 1997-1999. Page 214 in: Proc. 1st Asian Conf. Plant Pathol. G. H. Zhou and H. F. Li, eds. China Agriculture Science Technology Press, Beijing.

31. Roelfs, A. P., Singh, R. P., and Saari, E. E. 1992. Rust Diseases of Wheat: Concepts and Methods of Disease Management. CIMMYT, Mexico, D.F

32. Singh, R. P. 1991. Pathogenicity variations of Puccinia recondita f. sp. tritici and $P$. graminis f. sp. tritici in wheat-growing areas of Mexico during 1988 and 1989. Plant Dis. 75:790-794.

33. Singh, R. P., Chen, W. Q., and He, Z. H. 1999. Leaf rust resistance of spring, facultative, and winter wheat cultivars from China. Plant Dis. 83:644-651

34. Singh, R. P., Huerta-Espino, J., Pfeiffer, W., and Figueroa-Lopez, P. 2004 Occurrence and impact of a new leaf rust race on durum wheat in north- 
western Mexico from 2001 to 2003. Plant Dis. 88:703-708.

35. Wang, H. R. 1940. Notes on physiologic specialization in leaf rust of wheat in China. Phytopathology 37:680-681.

36. Wang, H. R., Yuan, J. S., Zhu, Z. Y., Wang, Y. X., and Zhao, L. B. 1987. Studies on physiological race of Puccinia recondita f. sp. tritici during 1973-1986. J. Hebei Agric. Univ. 10:158-171. (In Chinese with English abstract)

37. Wang, K. N., and Hong, X. W. 1982. Studies on physiological specialization of Puccinia recondita f. sp. tritici. Acta Phytopathol. Sin. 12:13-20. (In Chinese with English abstract)

38. Waterhouse, W. L. 1952. Australian rust studies. IX. Physiologic race determination and surveys of cereal rusts. Proc. Linn. Soc. N. S. W. 77:209-258.
39. Yang, W. X., Meng, Q. F., Feng, S. D., and Liu, D. Q. 2004. Virulence of Puccinia triticina on wheat in China in 1999. Acta Phytophylac. Sin. 31:4550. (In Chinese with English abstract)

40. Yuan, J. S., and Zhu, Z. Y. 1995. The study on growth and decline of physiological race of Puccinia recondita f. sp. tritici from 1993 to 1995. J. Hebei Agric. Univ. 18:134, 129. (In Chinese with English abstract)

41. Yuan, Z. Y., Wu, Y. P., Li, Y. F., and Zeng, W. F. 2005. Study on virulence genes of population of Puccinia recondita $\mathrm{f}$. sp. tritici in different wheat ecological areas of Shanxi. Chin. J. Eco-Agric. 13:144-146.

42. Zhao, X., Zheng, T., Xia, X., He, Z., Liu, D., Yang, W., Yin, G., and Li, Z. 2008. Molecular mapping of leaf rust resistance gene LrZH84 in Chinese wheat line Zhou 8425B. Theor. Appl. Genet. 117:1069-1075. 